\title{
Desain Database Menggunakan Microsoft Access Pada Siswa-Siswi SMK PGRI Kabupaten Brebes
}

\author{
Andri Widianto, Asrofi Langgeng Noerman Syah, Yeni Priatna Sari, Arief Zul Fauzi \\ Politeknik Harapan Bersama \\ Email: andri_widi@poltektegal.ac.id
}

\begin{abstract}
Abstrak
Tujuan pengabdian kepada masyrakat ini adalah memberikan pemahaman kepada siswa/l terkait dengan desain dan database menggunakan microsoft acsess. Kemajuan teknologi informasi khususnya terkait dengan program komputer yang dapat meningkatkan serta menunjang efektivitas dan efisiensi suatu proses bisnis. Oleh karenanya kemajuan teknologi informasi membuat organisasi di semua lini bisnis mengembangkan serta dan mengaplikasikan penggunaan teknologi untuk menghasilkan berbagai macam informasi. Database yang terkomputerisasi sangat menunjang kinerja dari suatu entitas, perancangan database perkantoran melalui microsoft acsess sangat membantu dalam pengolahan data serta memberikan informasi yang valid dalam pengambilan keputusan. Oleh karenanya siswa/i SMK PGRI Kabupaten Brebes perlu dibekali keterampilan dalam merancang serta membuat database menggunakan microsoft acsess. Metode yang digunakan dalam kegiatan pengabdian masyarakat ini adalah metode pelatihan dengan praktik langsung desain database melalui komputer yang tersedia di laboraturium komputer SMK PGRI Kabupaten Brebes. Kesimpulan kegiatan pengabdian kepada masyarakat ini adalah mayoritas siswa/i mengikuti pelatihan perancangan database dan dapat membuat serta mengoperasikan microsoft acsess yang dapat menjadi skill penunjang dalam menghadapi dunia kerja.
\end{abstract}

Kata Kunci: Database, Perancangan, Microsoft Acsess.

\begin{abstract}
The purpose of this activity is to provide understanding to students related to design and databases using microsoft acsess. Advances in information technology are particularly related to computer programs that can enhance and support the effectiveness and efficiency of a business process. Therefore, advances in information technology make organizations in all lines of business develop and apply the use of technology to produce various kinds of information. Computerized databases really support the performance of an entity. Office database design through Microsoft Access is very helpful in data processing and providing valid information in decision making. Therefore, students of SMK PGRI in Brebes Regency need to be equipped with skills in designing and creating databases using Microsoft Access. The method used in this community service activity is a training method with direct practice of database design through computers available in the computer laboratory of SMK PGRI, Brebes Regency. The conclusion of this community service activity is that the majority of students attend database design training and can create and operate Microsoft access which can be a supporting skill in facing the world of work.
\end{abstract}

Keywords: Database, Design, Microsoft Office 


\section{PENDAHULUAN}

Badan Pusat Statistik (BPS) mencatat jumlah pengangguran terbuka pada Agustus 2019 berjumlah 7,05 Orang, meningkat dari Agustus 2018 yang hanya 7 Juta Orang. Dalam pemaparannya Badan Pusat Statistik Suhariyanto tingkat pengangguran terbuka (TPT) didominasi oleh Sekolah Menengah Kejuruan (SMK) sebesar 10,42 persen pada Agustus 2019.(Fika Nurul Ulya, 2019). Ekonomi Indonesia di topang oleh industry dengan kontribusi terhadap Produk Domestik Bruto (PDB) hampir 20\%. Namun ironinya, disaat Indonesia di topang oleh sector industry manufaktur pengolahan, jumlah penggangguran SMK malah tinggi. (Tirta Citradi, 2019)

Pendidikan vokasi yang selama ini digadang-gadang menjadi sebuah solusi untuk menghasilkan tenaga terampil yang bisa terserap banyak di sector industry, akan tetapi sebaliknya, penguatan pendidikan vokasi perlu lebih ditingkatkan lagi dengan adanya peningkatan sesuai dengan bidang kompetensinya masing-masing apalagi jika dikombinasikan dengan kemajuan teknologi informasi khususnya terkait dengan program komputer yang dapat meningkatkan serta menunjang efektivitas dan efisiensi proses bisnis perusahaan. Oleh karenanya kemajuan teknologi informasi membuat organisasi di semua lini bisnis mengembangkan serta dan mengaplikasikan penggunaan teknologi untuk menghasilkan berbagai macam informasi salah satunya adalah database suatu perusahaan

Database yang terkomputerisasi sangat menunjang kinerja dari suatu entitas, perancangan database perkantoran melalui Microsoft Acsess sangat membantu dalam pengolahan data serta memberikan informasi yang valid dalam pengambilan keputusan. Microsoft Access (Microsoft Office Access) adalah sebuah program aplikasi basis data komputer relasional yang ditunjukan untuk kalangan industri rumahan dan perusahan kecil hingga menengah. Aplikasi ini menggunakan mesin basis data Microsoft Jet Database Engine, dan juga menggunakan tampilan grafis yang intuitif sehingga memudahkan pengguna untuk menggunakannya.(TM Books, 2014). Kegiatan Pengabdian Masyarakat yang dilakukan oleh Tim Pengabdian Masyarakat menjadi sebuah instrument untuk membekali siswa/i SMK PGRI Kabupaten Brebes dalam hal merancang serta membuat database menggunakan Microsoft Acsess. Sehingga mereka memiliki keterampilan lain sehingga dapat terserap oleh industry.

\section{METODE}

Jenis pengabdian kepada masyarakat Desain database untuk siswa/i SMK PGRI Kabupaten Brebes termasuk dalam kategori Iptek Bagi Masyarakat (IBM) yang dilaksanakan pada tanggal 5-6 Agustus 2019 di SMK PGRI Kabupaten Brebes dan diikuti oleh siswa/I SMK kelas XII beserta dengan guru pendamping. Dalam kegiatan pengabdian kepada masyarakat ini menggunakan metode ceramah dan metode pelatihan dengan praktik langsung melalui computer yang tersedia di laboraturium komputer SMK PGRI Kabupaten Brebes serta studi kasus terkait dengan perancangan database dalam suatu entitas. Dalam menyelesaikan masalah terkait dengan belum diberikannya materi tentang aplikasi perkantoran tersebut khususnya terkait dengan database menggunakan Microsoft Acsess maka kami merumuskan kerangka pemecahan maslah tersebut meliputi 3 hal utama, yaitu: Pengantar Microsoft Office, Desain Data Base dan Studi Kasus dan Praktik Mandiri Perancangan Database dalam suatu entitas. 


\section{HASIL \& PEMBAHASAN}

Untuk menjelaskan implementasi dari kerangka pemecahan masalah tersebut maka kegiatan pengabdian kepada masyarakat ini, kami materi yang disampaikan kepada peserta pelatihan meliputi : (Widianto, 2019)

a) Pengantar Microsoft Office

Siswa/i diberikan materi terlebih dahulu terkait dengan pengantar Microsoft Office seperti Microsoft Word, Microsoft Excell, Microsoft PPT, Microsoft Acsess, dan Lainnya

b) Desain Data Base

1. Desain Data Base Menggunakan Microsoft Access 2010
a) Untuk membuat database baru, Buka Microsoft Access 2010, Kemudian New "Blank Database" selanjutnya File Name dan Create
b) Untuk membuat lembar kerja yang berupa tabel seperti program excell pada umumnya yang berisi kolom disertai dengan baris yang berguna untuk input data, yaitu "Home" kemudian "View" selanjutnya "Desain View" kemudian "Save As" Table Name sesuai dengan keinginan saudara
c) Kemudian table disimpan "Save" sesuai dengan keinginan kemudian tabel diisi sesuai dengan yang direncanakan,
d) Apabila akan mengganti judul tabel maka harus klik " $X$ " kemudian Klik "Yes" database tersebut:
e) Setelah ditutup maka klik "Tabel" klik kanan "Rename"

2. Cara membuat rumus menghitung langsung dalam tabel database Microsoft Office access dapat dilakukan dengan mengikuti langkah-langkah sebagai berikut:

1. Tetapkan Kolom untuk membuat rumus/formula

2. Expand Combo box pada baris dan baris yang sudah ditetapkan untuk membuat formula

3. Pilih Calculate

4. Klick Saldo Persediaan

5. Tekan tanda * pada angka delapan (8) pada keyboard

6. Klick Banyaknya

7. Klick Ok

8. Simpan atau Ctrl S

9. Klick View yang berada dibagian kiri atas layar komputer/laptop untuk melihat hasilnya.

10. Hasil dari langkah-langkah yang dilakukan di atas akan tampak seperti gambar di bawah ini

3. Mendesain Formulir menggunakan Microsoft Access 2010

Formulir merupakan media input data dengan tampilan yang lebih baik dan lebih menarik. Adapun cara termudah untuk membuat formulir dengan menggunakan Form Wizard. Langkah-langkah pembuatan formulir berdasarkan tabel pada contoh sebelumnya adalah sebagai berikut:

1. Pilih table yang akan digunakan sebagai sumber pengisian formulir, sebagai contoh tabel persediaan motor. Pilih tabel Create, kemudian Forms dan klik Form Wizard.,

2. Tentukan Nama Formulir "Formulir Persediaan Motor"

3. Setelah ditentukan nama formulirnya, kemudian klik Finish

C). Studi Kasus dan Praktik Mandiri Perancangan Database dalam suatu entitas 


\section{KESIMPULAN DAN SARAN}

Kesimpulan dari kegiatan pengabdian kepada masyarakat menggambarkan bahwa Desain database untuk siswa/i SMK PGRI Kabupaten Brebes sangat bermanfaat karena mayoritas siswa/i belum familiar atau menggunakan Microsoft Acsess sehingga peserta mengungkapkan akan rasa pentingya pelatihan desain database menggunakan Microsoft Acsess. Kegiatan pengabdian kepada masyarakat ini tentunya bukan tanpa kendala sehingga saran dalam pengabdian masyarakat ini yaitu perlu dilakukan pendampingan secara terus menerus agar siswa/i mampu mengaplikasikan dan dipraktikan dalam kehidupan seharihari.

\section{UCAPAN TERIMA KASIH}

Ucapan terima kasih yang sebesar-besarnya kami ucapkan kepada : Politeknik Harapan Bersama Tegal yang telah memberikan dukungan dana kepada kami sehingga kami dapat merealisasikan kegiatan pengabdian kepada masyarakat, selanjutnya adalah untuk seluruh peserta pelatihan yang selalu semangat dan antusias dalam mengikuti pelatihan desain database selama 2 hari.

\section{DAFTAR PUSTAKA}

Fika Nurul Ulya. (2019). BPS: Pengangguran Meningkat, Lulusan SMK Mendominasi. Kompas.Com. $\quad$ https://money.kompas.com/read/2019/11/05/155358926/bpspengangguran-meningkat-lulusan-smk-mendominasi\#: :text=Selain SMK\%2C SMA menempati peringkat,dan SD 2\%2C41 persen.

Tirta Citradi. (2019). Miris! Tingkat Pengangguran Terbuka Lulusan SMK Paling Tinggi. https://www.cnbcindonesia.com/news/20191105151115-4-112837/miris-tingkatpengangguran-terbuka-lulusan-smk-paling-tinggi

TM Books. (2014). Sistem Informasi Akuntansi Konsep dan Penerapan. Penerbit ANDI.

Widianto, A. (2019). Praktikum Sistem Informasi Akuntansi. Program Studi D3 Akuntansi Politeknik Harapan Bersama. 


\section{LAMPIRAN :}

Ilustrasi Pengabdian Kepada Masyarakat dapat di lihat dalam gambar dibawah ini:
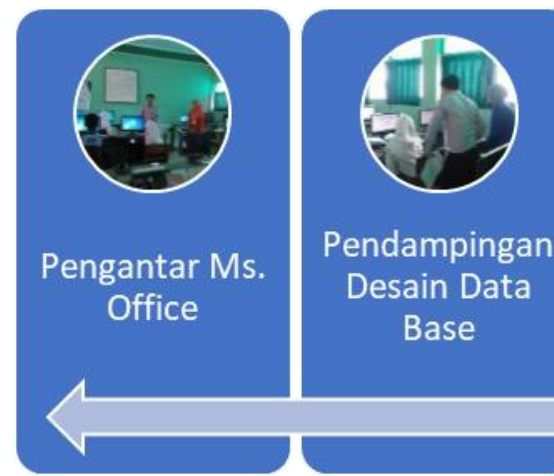

Pendampingan

Desain Data

Base

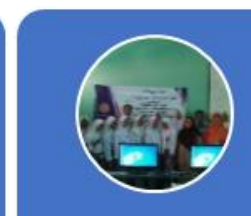

Sesi Photo

Bersama

Gambar 1. Ilustrasi Kegiatan Pengabdian Masyarakat

Gambar 2. Kerangka Pemecahan Masalah

TABEL 1. STUDI KASUS DESAIN DATABASE

PT ANDROMEDA

Taksiran Kerugian Piutang 31 Desember 2017

\begin{tabular}{|c|c|c|c|}
\hline Kelompok Umur & Jumlah & $\begin{array}{c}\text { Prosentase } \\
\text { Kerugian Piutang }\end{array}$ & $\begin{array}{c}\text { Taksiran } \\
\text { Kerugian Piutang }\end{array}$ \\
\hline Belum Menunggak & Rp 3.000.000 & 50 & Rp 1.500.000 \\
\hline Menunggak 1-30 hari & $\operatorname{Rp} 2.500 .000$ & 1 & $\begin{array}{ll}\text { Rp } & 25.000\end{array}$ \\
\hline Menunggak 31-60 hari & Rp 4.500.000 & 3 & 135.000 \\
\hline Menunggak 61-90 hari & Rp 2.500.000 & 5 & 125.000 \\
\hline Lebih dari 90 hari & Rp 1.500 .000 & 7 & 105.000 \\
\hline Jumlah & Rp 14.000.000 & & Rp 1.890 .000 \\
\hline
\end{tabular}

Buatlah tabel dan formulir Taksiran Kerugian Piutang PT Andromeda menggunakan Microsoft Access 2010??? 